\title{
Characterization of Soil and Sediment Parameters of Jisike-Izombe Upper Aquifer System for Assessment of the Potential of Groundwater Pollution
}

\author{
*11T.U.S ONYEOBI; CN AKUJIEZE
}

\author{
Department of Geology, Faculty of Physical Sciences \\ University of Benin, Benin City, Nigeria.
}

\begin{abstract}
The JES field, an onshore field in the Jisike - Izombe area of southeastern Nigeria had a number of oil-producing wells before it was abandoned over a decade ago. By means of soil/sediment samples retrieved from three strategically located boreholes around the field, the subsurface units were delineated and the physical characteristics of the vadose zone were determined in order to predict the groundwater pollution potential of the upper aquifer system in the area. Ground conditions were found to be approximately 1 metre (3.043ft) of loamy top soil overlying about 1.2 metres $(3.65 \mathrm{ft})$ of clayey laterite which overlies $19.4-24.6$ metres i.e $(60 \mathrm{ft}-75 \mathrm{ft})$ of reddish-brown silty sand, beneath which is medium - coarse grained white sand which constitutes the aquifer system with estimated hydraulic conductivity in the range $1 \times 10^{-1}$ to $169 \times 10^{-1} \mathrm{~mm} / \mathrm{sec}$. Flow analysis of groundwater indicates a southwesterly flow with the River Niger as possible discharge zone. The high leaching potentials and high transmissive properties of the sediments below the clayey laterite suggests a vulnerability of the aquifer to pollution through vertical infiltration. However, borehole water quality parameters for the area show that groundwater quality is not in anyway compromised when compared to the WHO limits. Rather, it is argued that the groundwater is naturally well protected by the upper part of the vadose zone where the clayey lateritic soil with iron oxide cementation of soil particles provides an appreciable degree of barrier to downward movement of contaminants. Because of the clayey behavior of the near-surface soils and their affinity for the retention of contaminants, it is concluded that the area is not a locus of groundwater pollution. (C) JASEM
\end{abstract}

http://dx.doi.org/10.4314/jasem.v18i4.17

\section{Introduction}

Petroleum activity (exploration and exploitation) has been on for many years over a vast area in the Niger Delta region of Nigeria covering some $6400 \mathrm{~km}^{2}$ on-shore and $76,000 \mathrm{~km}^{-2}$ off-shore. The JES field located in the Jisike - Izombe area of southeastern Nigeria is one of the on-shore oil fields within an estimated total land area of about $3.95 \mathrm{~km}^{2}$. It was discovered in 1975 and is adjacent to and east of Izombe field. The entire area lies between longitudes $6^{0} 50^{\prime}$ and $6^{0} 53^{\prime}$ East, and latitudes $5^{\circ} 36^{\prime}$ and $5^{0} 38^{\prime}$ North.

As a consequence of petroleum operations, different aspects of the geo-environment (e.g soil and groundwater) may be vulnerable to pollution and degradation. It is therefore imperative to carry out an Environmental Impact Assessment (EIA) as a sine-qua-non of a field development plan (FDP) prior to the commencement of the project. Where this had not been done, prediction of impacts of petroleum activity would then be based on a postimpact assessment (PIA) and environmental evaluation report (EER) relying essentially on control samples, since baseline data would not be available. Any of these studies would entail gathering of data that govern the transfer of contaminants and wastes from the site down to the groundwater. With regards to groundwater, it is often necessary to characterize the geomaterials above the aquifer (vadose zone) because of the need for groundwater protection against pollution.

Geological factors of soils and sediments must be identified so that their ability to transport pollutants can be ascertained, including lateral changes (facies changes) in the formation. For example, many non-aqueous phase liquids (NAPLs) which are volatile organic compounds of environmental concern (gasoline, chlorinated solvents etc) frequently enter groundwater systems after they have been spilled on the surface, and pass through the unsaturated zone (Palmer and Johnson, 1991). Impacts on soil quality from pollutants, which may be direct, could also be quite significant (Petts and Eduljee, 1994). Therefore, an understanding 
of site geology and soils is essential in relation to

(i) prediction of leachate impact and

(ii) prediction of ecological and human health impacts.

The ultimate goal of site characterization is to make informed decisions and one of the objectives is to predict/establish the impacts of certain facilities or natural phenomena on water quality under a variety of conditions (Mercer and Spalding 1991). Inevitably, an assessment of the groundwater flow system is necessary as is the assessment of the contamination in the groundwater. The latter involves groundwater quality monitoring over a period of time.

This contribution presents soil and sediment characteristics of the upper aquifer system of the Jisike - Izombe area as a tool for assessment of the potential of groundwater pollution.

\section{METHODOLOGY}

Three boreholes, strategically located such that they form a triangular pattern, were drilled near the oil field by the rotary method using a water-based drilling mud. The boreholes $\mathrm{BH}_{1}, \mathrm{BH}_{2}$ and $\mathrm{BH}_{3}$ (Fig.1) terminated at depths about 2metres after groundwater was encountered. Soil and sediment samples were collected according to the dictates of changes in physical characteristics with depth. Borehole water samples were collected after the well had been pumped sufficiently to ensure a particulate free sample (purging), representing ground source. Coordinates of the three locations

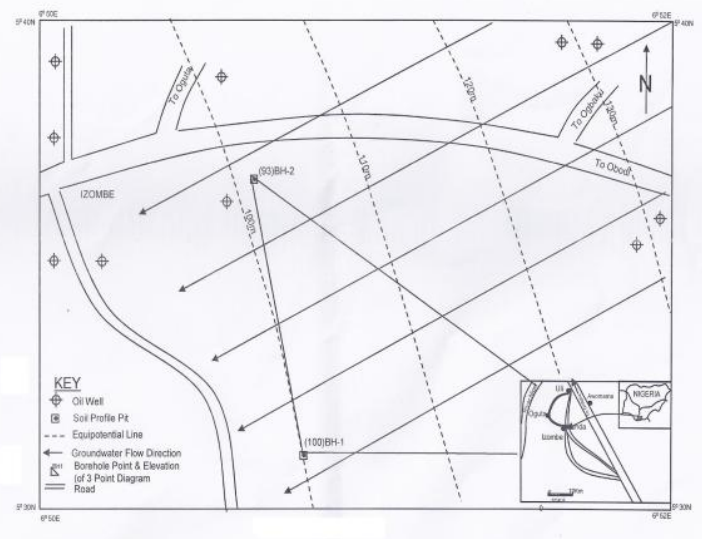

FIG. 1: GROUNDWATER FLOW DIRECTION IN JESIKE OIL FIELD AND SAMPLING POINTS (INSET NIGERIA)

Fig. 1: Groundwater Flow Direction in JES Oil Field and Sampling Points (Inset Study Area, Nigeria)
(Please fill in this gap)

together with ground elevations and water table elevations are given in Table 2. Particle size analyses of the soils/sediments were conducted in accordance with BS1377 (1990) for each of the three boreholes. Soil classification was based on the uniformity coefficient of the size distribution.

i.e $U C=\frac{D_{60}}{D_{10}}$ where $\mathrm{D}_{10}$ is the effective particle size in mm. Hydraulic properties were estimated as hydraulic conductivity using Hazen's formula: $K=10 D_{10}^{2} \mathrm{~mm} / \mathrm{s}$ or Seelheim's formula $\mathrm{k}=$ $0.00357 \mathrm{D}_{50}^{2}$ where $\mathrm{D}_{10}$ is indeterminate.

Selected physico-chemical parameters (available phosphorus, conductivity, chloride content, $\mathrm{pH}$, organic matter content, total hydrocarbon etc) were determined for the top soil and control samples at depths of $15-30 \mathrm{~cm}, 30-60 \mathrm{~cm}$ and $60-90 \mathrm{~cm}$ while the borehole water samples were analysed for the following quality parameters: $\mathrm{pH}$, total solids, total hydrocarbon content (THC), total hardness, chlorides, sulphates $\mathrm{Cu}, \mathrm{Fe}, \mathrm{Mn}, \mathrm{Zn}$, and $\mathrm{Pb}$. The results were compared to the WHO limits for drinking water with a view to establishing negative impacts, if any, consequent on past petroleum operations.

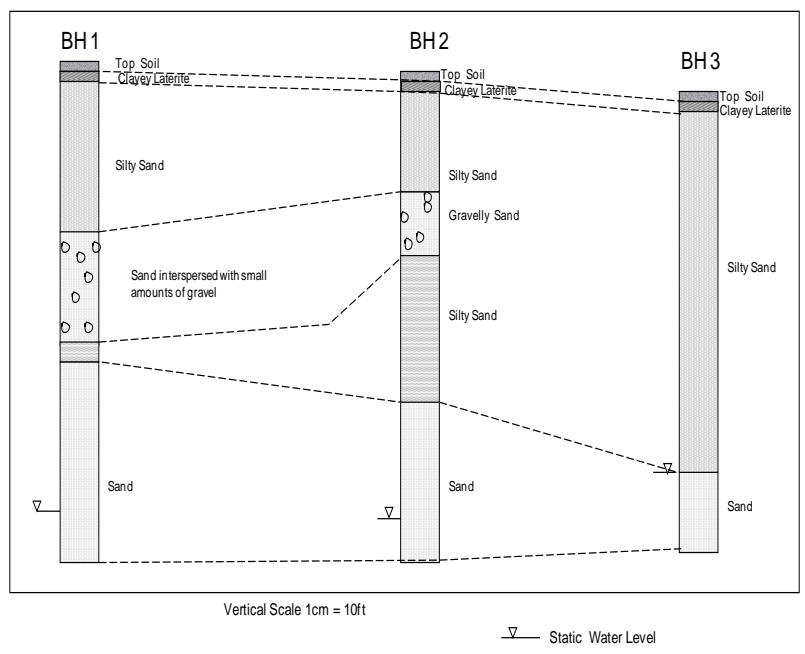

FIG. 2: LITHOLOGIC LOG OF THE THREE BOREHOLES 
Geology of the Area: The specific site within the area of study lies at elevations of between 210 feet (69 metres) and 230feet (75 metres) above sea level and slopes gently in a southwesterly direction. The area is underlain by the Benin Formation (Oligocene - Pliocene) which together with the Agbada Formation and the Akata Formation constitute the three chronostratigraphic units that have been recognized and described in the subsurface of the Niger Delta Basin (Short and Stauble, 1967; Hospers, 1971; Avbovbo, 1978).

Lithologically, the Benin Formation consists of over $90 \%$ sand with occasional clay/shale intercalations (Short and Stauble, 1967). The sands, which are medium to coarse grained are generally white in colour with a reddish brown lateritic top due to feruginization of surface materials. Texturally, they are subangular to well rounded consisting largely of quartz and minor amounts of feldspar. They are generally poorly sorted but well sorted in places.

Clays are known to be prominent in the formation westwards of Benin City. The clay layers and lenses are generally greyish-brown. Local textural variations are megascopically discernible in places. Due to its predominantly sandy nature, and the fact that it is underlain by the relatively less permeable Ogwashi - Asaba Formation, the Benin Formation is known to have very good aquifer properties. Most prolific boreholes around Benin City tap from this formation (Adetola et al, 1999). Table 1 is a summary of the stratigraphy of the Niger Delta. The Agbada Formation is considered as a down-dip continuation of the Ogwashi-Asaba Formation.

Table 1: Summary of Stratigraphy of the Niger Delta

\begin{tabular}{|l|l|l|}
\hline Age & Formation & Lithology \\
\hline Oligocene to Pliocene & Benin Formation (youngest) & $\begin{array}{l}\text { Continental sands - over 90\% sandstone, with clayey and pebbly } \\
\text { layers }\end{array}$ \\
\hline Eocene to Pleistocene & Agbada Formation & $\begin{array}{l}\text { Upper predominantly sandy unit with minor clay intercalations, and } \\
\text { lower clay unit thicker than upper sandy unit. Rich in micro fauna at } \\
\text { the base. }\end{array}$ \\
\hline Eocene to Miocene & Akata Formation (Oldest) & $\begin{array}{l}\text { Uniform shale development consisting of dark gray sandy silty shale. } \\
\text { Rich in micro fauna. }\end{array}$ \\
\hline
\end{tabular}

Table 2: Coordinates of Borehole Locations and Static groundwater levels

\begin{tabular}{|l|l|l|l|l|l|}
\hline $\begin{array}{l}\text { Borehole } \\
\text { No }\end{array}$ & Eastings & Northings & $\begin{array}{l}\text { Ground Elevation } \\
\text { (Feet) }\end{array}$ & $\begin{array}{l}\text { Depth to } \\
\text { Static Water } \\
\text { Level (Feet) }\end{array}$ & $\begin{array}{l}\text { Groundwater } \\
\text { Elevation (Feet) }\end{array}$ \\
\hline BH1 & $6^{0} 50.26$ & $5^{0} 36.62$ & 220 & 120 & 100 \\
\hline BH2 & $6^{0} 50.04$ & $5^{0} 37.40$ & 217 & 120 & 97 \\
\hline BH3 & $6^{0} 51.25$ & $5^{0} 36.63$ & 226 & 100 & 126 \\
\hline
\end{tabular}

\section{RESULTS AND DISCUSSION}

The granulometric data and other physical attributes of the soil/sediment samples from the three boreholes are listed in Tables 3A, 3B and 3C which also show the lithologic logs in minute details. Figure 2 illustrates, in a pictorial fashion, the lithologic correlation of the subsurface geological materials in the area. The microstratigraphy of the area as revealed by borehole drilling clearly shows a lithologic distribution comprising four main units: a top soil (approximately $1 \mathrm{~m}$ thick) consisting essentially of light-brown, fine-grained loamy soil with a greyish to a grey-brown hue characterized by the presence of plant rootlets. This is underlain by approximately $1.2 \mathrm{~m}$ of fairly indurated clayey lateritic soil which in turn overlies 60 to 75 feet of reddish-brown silty sand, gravelly in places.
Here, the proportion of silt-size particles is clearly subordinate $(<10 \%)$. However, the lateral continuity of this unit is broken in BH1 and $\mathrm{BH} 2$ by reddish brown medium to coarse-grained silty sand interspersed with gravel. Below the reddish brown silty sand is a coarse to medium-grained whitish sand which constitutes the main aquifer system in the area. Groundwater was encountered at relatively shallow depths ranging from 100 to 120 feet from existing ground level.

The properties of the sediments listed in Tables 3A, $3 \mathrm{~B}$ and $3 \mathrm{C}$ show that below the clayey laterite, estimated hydraulic conductivity is in the range $1 \times 10^{-1}$ to $169 \times 10^{-1} \mathrm{~mm} / \mathrm{s}$ (BH1) $2.10 \times 10^{-1}$ to $81 \times 10^{-}$ ${ }^{1} \mathrm{~mm} / \mathrm{s}$ (BH2) and $1.23 \times 10^{-2}$ to $18.6 \times 10^{-1} \mathrm{~mm} / \mathrm{s}$ (BH3). These values are typical of medium to coarse-grained sand. More importantly, hydraulic 
conductivity generally increases with depth, excluding the top near-surface

units that are characterized by considerably smaller transmissive properties. (hydraulic conductivity
$3.66 \times 10^{-5}-5.7 \times 10^{-5} \mathrm{~mm} / \mathrm{s}$ for all three boreholes). These values are typical of silts (Smith, 1978) or very fine sands, silts and clay-silt (Craig, 1994).

Table 3A: Physical Parameters and Classification of Borehole Soil Samples

\begin{tabular}{|c|c|c|c|c|c|c|c|c|c|c|c|c|}
\hline \multirow{2}{*}{$\begin{array}{l}\text { Boreh } \\
\text { ole } \\
\text { No }\end{array}$} & \multirow{2}{*}{$\begin{aligned} \begin{array}{l}\text { Depth } \\
\text { (feet) }\end{array} & \end{aligned}$} & \multicolumn{4}{|c|}{ Particle Size Distribution } & \multirow[t]{2}{*}{$\mathrm{D}_{60}(\mathrm{~mm})$} & \multirow{2}{*}{$\begin{array}{l}\mathrm{D}_{10} \\
(\mathrm{~mm}) \\
\text { (effective } \\
\text { size) }\end{array}$} & \multirow{2}{*}{$\begin{array}{l}\text { Uniformity } \\
\text { Coefficient } \\
\text { (UC) }\end{array}$} & \multirow{2}{*}{$\begin{array}{l}\text { Hydraulic } \\
\text { Conductivity } \\
\mathrm{mm} / \mathrm{sec}\end{array}$} & \multirow{2}{*}{$\begin{array}{l}\text { Sample } \\
\text { Description }\end{array}$} & \multirow{2}{*}{$\begin{array}{l}\text { Soil } \\
\text { Classification } \\
\text { (USC) }\end{array}$} & \multirow{2}{*}{$\begin{array}{l}\text { Soil } \\
\text { Leaching } \\
\text { potential }\end{array}$} \\
\hline & & \% Clay & $\begin{array}{l}\% \\
\text { Silt }\end{array}$ & $\%$ Sand & $\%$ Gravel & & & & & & & \\
\hline \multirow{14}{*}{ BH1 } & 2.5 & 17 & 58 & 25 & - & 0.038 & $* *$ & *** & $3.66 \times 10^{-5}$ & Light gray-light brown loamy & $\mathrm{ML}$ & $\mathrm{VL}$ \\
\hline & 5.0 & 25 & 48 & 27 & - & 0.045 & *** & *** & $5.16 \times 10^{-5}$ & Reddish brown clayey laterite & ML & $\mathrm{VL}$ \\
\hline & 10.0 & - & - & 100 & - & 0.525 & 0.200 & 2.63 & $4.0 \times 10^{-1}$ & Reddish-brown, lateritic uniformly sand & SU & VH \\
\hline & 20.0 & - & 5.0 & 95.0 & - & 0.615 & 0.230 & 2.67 & $5.29 \times 10^{-1}$ & Reddish brown, lateritic uniformly graded silty sand & SU & $\mathrm{VH}$ \\
\hline & 30.0 & - & 8.0 & 92.0 & - & 0.570 & 0.100 & 5.70 & $1.0 \times 10^{-1}$ & Reddish brown well graded lateritic silty sand & SU & $\mathrm{VH}$ \\
\hline & 40.0 & - & 6.0 & 94.0 & - & 0.800 & 0.175 & 4.57 & $3.06 \times 10^{-1}$ & Reddish brown, uniformly graded, lateritic silty sand & SU & $\mathrm{VH}$ \\
\hline & 50.0 & - & - & 97.5 & 2.5 & 1.200 & 0.400 & 3.00 & $16.0 \times 10^{-1}$ & Light brown, lateritic gravelly sand & SU & $\mathrm{VH}$ \\
\hline & 70.0 & - & - & 96.5 & 3.5 & 1.150 & 0.400 & 2.88 & $16.0 \times 10^{-1}$ & “ & SU & $\mathrm{VH}$ \\
\hline & 80.0 & - & - & 100 & - & 1.180 & 0.600 & 1.97 & $36.0 \times 10^{-1}$ & $\begin{array}{l}\text { Light coloured, uniformly graded, medium-coarse } \\
\text { grained sand }\end{array}$ & SU & $\mathrm{VH}$ \\
\hline & 90.0 & - & - & 100 & - & 1.800 & 1.300 & 1.38 & $169 \times 10^{-1}$ & " & SU & $\mathrm{VH}$ \\
\hline & 100 & - & - & 100 & - & 0.830 & 0.475 & 1.75 & $22.6 \times 10^{-1}$ & " & SU & $\mathrm{VH}$ \\
\hline & 110 & - & - & 100 & - & 0.700 & 0.400 & 1.75 & $16.0 \times 10^{-1}$ & $"$ & SU & $\mathrm{VH}$ \\
\hline & 120 & - & - & 100 & - & 0.425 & 0.150 & 2.83 & $2.25 \times 10^{-1}$ & " & SU & VH \\
\hline & 130 & - & - & 100 & - & 0.500 & 0.180 & 2.78 & $3.24 \times 10^{-1}$ & " & & $\mathrm{VH}$ \\
\hline
\end{tabular}

** Indeterminate

Table 3B: Physical Parameters and Classification of Borehole Soil Samples

**Indeterminate

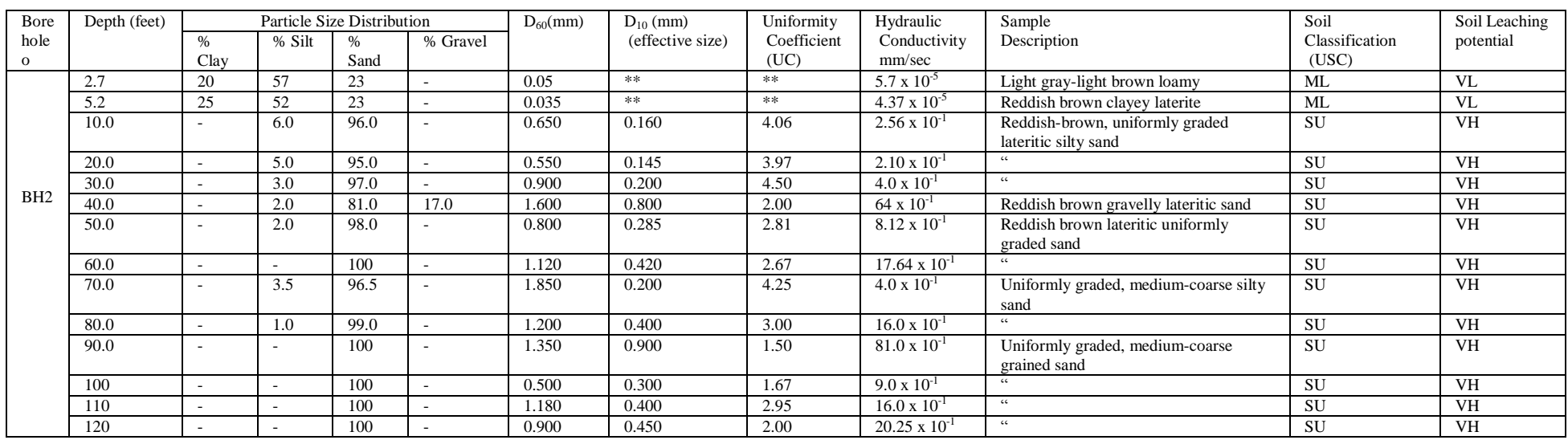

Table 3C: Physical Parameters and Classification of Borehole Soil Samples ** Indeterminate

\begin{tabular}{|c|c|c|c|c|c|c|c|c|c|c|c|c|}
\hline \multirow{2}{*}{$\begin{array}{l}\text { Bore } \\
\text { hole } \\
\text { No }\end{array}$} & \multirow{2}{*}{$\begin{array}{r}\text { Depth } \\
\text { (feet) }\end{array}$} & \multicolumn{4}{|c|}{ Particle Size Distribution } & \multirow{2}{*}{$\mathrm{D}_{60}(\mathrm{~mm})$} & \multirow{2}{*}{$\begin{array}{l}\mathrm{D}_{10}(\mathrm{~mm}) \\
\text { (effective size) }\end{array}$} & \multirow{2}{*}{$\begin{array}{l}\text { Uniformity } \\
\text { Coefficient (UC) }\end{array}$} & \multirow{2}{*}{$\begin{array}{l}\text { Hydraulic } \\
\text { Conductivity } \\
\mathrm{mm} / \mathrm{sec}\end{array}$} & \multirow{2}{*}{ Sample Description } & \multirow{2}{*}{$\begin{array}{l}\text { Soil } \\
\text { Classifica } \\
\text { tion } \\
\text { (USC) }\end{array}$} & \multirow{2}{*}{$\begin{array}{l}\text { Soil Leaching } \\
\text { potential }\end{array}$} \\
\hline & & $\%$ Clay & $\%$ Silt & $\%$ Sand & $\%$ Gravel & & & & & & & \\
\hline \multirow{13}{*}{ BH3 } & 2.5 & 20 & 55 & 25 & - & 0.04 & $* *$ & $* *$ & $5.7 \times 10^{-5}$ & Light gray-light brown loamy & ML & $\mathrm{VL}$ \\
\hline & 6.0 & 25 & 52 & 23 & - & 0.038 & $* *$ & *** & $5.16 \times 10^{-5}$ & Reddish brown clayey laterite & ML & $\mathrm{VL}$ \\
\hline & 10.0 & - & 6.0 & 94.0 & - & 0.520 & 0.245 & 2.12 & $6.0 \times 10^{-1}$ & Reddish-brown, lateritic silty sand & SU & $\mathrm{VH}$ \\
\hline & 20.0 & - & 4.5 & 95.5 & - & 0.320 & 0.110 & 2.91 & $1.21 \times 10^{-1}$ & $\begin{array}{l}\text { Reddish-brown, uniformly graded } \\
\text { silty sand }\end{array}$ & SU & $\mathrm{VH}$ \\
\hline & 30.0 & - & 3.0 & 97.0 & - & 0.500 & 0.150 & 3.33 & $2.25 \times 10^{-1}$ & $\begin{array}{l}\text { Light-brown lateritic uniformly } \\
\text { graded silty sand }\end{array}$ & SU & $\mathrm{VH}$ \\
\hline & 40.0 & - & 3.0 & 97.0 & - & 0.520 & 0.250 & 2.08 & $6.25 \times 10^{-1}$ & $\begin{array}{l}\text { Light-brown lateritic uniformly } \\
\text { graded silty sand }\end{array}$ & $\mathrm{SU}$ & $\mathrm{VH}$ \\
\hline & 50.0 & - & 2.0 & 98.0 & - & 0.750 & 0.285 & 2.63 & $8.12 \times 10^{-1}$ & $\begin{array}{l}\text { Light-brown lateritic uniformly } \\
\text { graded silty sand }\end{array}$ & SU & $\mathrm{VH}$ \\
\hline & 60.0 & - & 2.0 & 98.0 & - & 0.750 & 0.285 & 2.63 & $8.12 \times 10^{-1}$ & $\begin{array}{l}\text { Light-brown lateritic uniformly } \\
\text { graded silty sand }\end{array}$ & SU & $\mathrm{VH}$ \\
\hline & 70.0 & - & - & 100 & - & 0.500 & 0.300 & 1.67 & $9.0 \times 10^{-1}$ & $\begin{array}{l}\text { Light-brown lateritic uniformly } \\
\text { graded silty sand }\end{array}$ & $\mathrm{SU}$ & $\mathrm{VH}$ \\
\hline & 80.0 & - & - & 100 & - & 0.810 & 0.325 & 2.49 & $10.56 \times 10^{-1}$ & $\begin{array}{l}\text { Light-brown lateritic uniformly } \\
\text { graded silty sand }\end{array}$ & $\mathrm{SU}$ & $\mathrm{VH}$ \\
\hline & 90.0 & - & - & 100 & - & 0.750 & 0.380 & 1.97 & $14.4 \times 10^{-1}$ & $\begin{array}{l}\text { Light-brown lateritic uniformly } \\
\text { graded silty sand }\end{array}$ & SU & $\mathrm{VH}$ \\
\hline & 100 & - & - & 100 & - & 0.700 & 0.420 & 1.67 & $17.6 \times 10^{-1}$ & $\begin{array}{l}\text { Light-brown lateritic uniformly } \\
\text { graded silty sand }\end{array}$ & $\mathrm{SU}$ & $\mathrm{VH}$ \\
\hline & 110 & & - & 100 & - & 0.680 & 0.415 & 1.64 & $17.2 \times 10^{-1}$ & $\begin{array}{l}\text { Light-brown lateritic uniformly } \\
\text { graded silty sand }\end{array}$ & $\mathrm{SU}$ & $\mathrm{VH}$ \\
\hline
\end{tabular}


Flow analysis of groundwater based on water table measurements was carried out. This involved the measurement of depths to water level in each of the boreholes by means of a water level indicator, while elevation of each of the boreholes was determined by means of a GPS. The water level depths so obtained, were converted to elevation data (Table 2) followed by a mechanical contouring technique to establish the dominant flow direction, since groundwater flows in a direction orthogonal to the contours from a higher to a lower potentiometric surface. The result of the analysis indicates a southwesterly flow of groundwater with the River Niger as a possible discharge zone. Figure 1 shows the flow direction, an indication of potential paths for leachate and contaminant migration. It is noteworthy, that although flow direction takes site-specific geology into account, variability could occur over a period of time, considering recharge to or withdrawal from the aquifer.
Top Soil Leaching Potentials And Mobility Of Ions: The top soil $(0-90 \mathrm{~cm})$ of the area was studied with a view to assessing their leaching potentials and mobility of ions. In general terms, based on sand fractional content, the soil leaching potentials vary from very low at the top to very high at depth (below top soil and clayey laterite). The lithologs of $\mathrm{BH} 1, \mathrm{BH} 2$ and $\mathrm{BH} 3$ show that the near surface soils consist, for the most part, of fines, (i.e silt and clay) ranging from $73 \%$ to $77 \%$, with about $25 \%$ sand-size particles. Applying the scale of Brown et al (1997, Table 4) the leaching potentials of the top soil and clayey lateritic soil are rated as very low, a situation that is corroborated by the profile variations of such mobile ions as available phosphorus and chlorides with depth. However, there is a drastic change in leaching potential beyond 2.2 metres from low to very high. This a reflection of the change in the texture of the soil and aquifer formation to greater than $90 \%$ sand fraction with depth.

Table 4: Scale of Soil Leaching Potential (Brown et al., 1997)

\begin{tabular}{|l|l|}
\hline Texture & Leaching Potential \\
\hline$(90-100) \%$ Sand Fraction & V.H (Very High Potential $)$ \\
\hline$(70-89) \%$ Sand Fraction & High Potential \\
\hline$(50-69) \%$ Sand Fraction & I Intermediate Potential \\
\hline$(30-49) \%$ Sand Fraction & L Low Potential \\
\hline$(<30) \%$ Sand Fraction & V.L. Very Low Potential \\
\hline
\end{tabular}

Physico-Chemical Properties Of The Top Soil: The soils of the studied area are acidic with $\mathrm{pH}$ values ranging from 5.03 to 6.9 (Table 5). There is no significant difference between the $\mathrm{pH}$ values and those of the "control" samples and neither of the results depicts any discernible trend in terms of variation with depth. The conductivity values are relatively low with a range of $20-48.08 \mu \mathrm{s} / \mathrm{cm}$ but these values are slightly higher than those recorded for control samples. They reflect low electrolyte concentration in the soil and, to a large extent, the continental, non-marine nature of the Benin Formation.
The soils were found to have low organic matter content $(0.65-2.65)$ consistent with their lateritic nature. Expectedly, the highest values were associated with the top $0-30 \mathrm{~cm}(1.68-2.65)$ and are generally higher than those of the control samples. Available phosphorus was the most abundant macronutrient $(79.30-96.90)$. Their mean values were slightly higher than values recorded for the control samples. The total hydrocarbon content, a strong indicator of petroleum pollution, was not so high (15.07 - 68.14) and although higher than those of control samples, betrayed no strong inkling of hydrocarbon contamination in the soil. There is, however, subtle evidence of contaminant retention in the near-surface zone

Table 5: Physico-Chemical Properties of Composite and Control Soil

Samples for the Area

\begin{tabular}{|c|c|c|c|c|c|c|c|c|}
\hline & $\begin{array}{l}\text { Depth } \\
\text { Range }(\mathrm{cm})\end{array}$ & $\mathrm{pH}$ & $\begin{array}{l}\text { Available } \\
\text { Phosphorus }\end{array}$ & $\begin{array}{l}\text { Cation Exchange } \\
\text { Capacity Mmol/Kg }\end{array}$ & $\begin{array}{l}\text { Chloride } \\
\text { ppm }\end{array}$ & $\begin{array}{l}\text { Conductivity } \\
\mu \mathrm{s} / \mathrm{cm}\end{array}$ & THC & $\begin{array}{l}\text { Organic Matter } \\
\text { Content }(\%)\end{array}$ \\
\hline \multirow{4}{*}{$\begin{array}{l}\tilde{o} \\
\tilde{\Xi} \\
\tilde{\Xi} .\end{array}$} & $0-15$ & 5.03 & 96.90 & 115.95 & 2.68 & 20.4 & 56.2 & 1.08 \\
\hline & $15-30$ & 6.90 & 72.0 & 214.0 & 2.84 & 40.72 & 68.14 & 2.65 \\
\hline & $30-60$ & 6.11 & 79.30 & 186.02 & 1.89 & 41.60 & 51.6 & 0.96 \\
\hline & $60-90$ & 5.86 & 86.8 & 200.2 & 1.19 & 48.08 & 22.7 & 0.65 \\
\hline \multirow{4}{*}{$\begin{array}{l}\overline{0} \\
\text { : } \\
\text { ర0 }\end{array}$} & $0-15$ & 5.81 & 105.0 & 195.58 & 1.84 & 48.2 & 42.5 & 0.64 \\
\hline & $15-30$ & 5.25 & 25.50 & 83.70 & 1.78 & 20.5 & 28.7 & 0.69 \\
\hline & $30-60$ & 5.75 & 80.70 & 100.10 & 1.77 & 26.5 & 31.6 & 0.60 \\
\hline & $60-90$ & 5.11 & 45.0 & 171.12 & 1.76 & 30.4 & 19.2 & 1.21 \\
\hline
\end{tabular}


Implications Of Textural Characteristics: The vadose zone, for the most part, is characterized by high leaching potential and as such is less well suited to provide attenuation of contaminants. This is because cation exchange and buffering apacities are known to be limited in most sandstone strata except where they are clayey. Significantly, the predominantly arenaceous nature of the materials encountered in this section as revealed by the borehole soil samples, suggests that these granular materials would have little attraction, if any, for toxic metals and industrial organics such as hydrocarbons. Sediment contamination which is usually governed by both physical and chemical properties (Moore and Newbry, 1976; Khalid et al., 1977) would, therefore, be expected to be minimal especially as the sands are composed mainly of quartz grains. Under normal circumstances, these are factors that would favour easy rainfall infiltration and concomitant entry of any transported contamination into the groundwater via the vadose zone.

However, the uppermost section of the vadose zone consists of clayey laterite with iron oxide coating and cementation of soil particles. The top soil is also loamy thus providing a natural barrier to groundwater pollution. Here, contaminants could be purified by processes such as anaerobic decomposition, filtration, ion exchange and adsorption (Petts and Eduljee, 1994).

With the presence of the top soil cover and clayey laterite, the upper aquifer would not be vulnerable to pollution. The groundwater quality parameters for the area (Table 6) attest to this inference as all the values fall within the WHO permissible limits for drinking water although microbiological data are not included. It is possible that any break in the soil at the surface leading to the removal of the top soil and clayey laterite could render the upper aquifer highly vulnerable to pollution. Where that happens, groundwater contaminants have the potential to move more rapidly in the aquifer unit with high hydraulic conductivity. Therefore, because of the high transmissive properties of the sediments, groundwater flow rates would be high and contaminant transport fast.

Table 6: Range of Groundwater quality parameters for borehole water samples in the study area compared with WHO limits for drinking water.

\begin{tabular}{|l|l|l|l|}
\hline \multirow{2}{*}{ Parameters } & \multirow{2}{*}{ Range } & $\begin{array}{l}|c| \\
\text { Highest desirable } \\
\text { level }\end{array}$ & $\begin{array}{l}\text { Maximum } \\
\text { Permissible } \\
\text { level }\end{array}$ \\
\hline $\mathrm{pH}$ & & & $6.5-9.2$ \\
\hline Total solids mg/l & $108-113$ & 500 & 1500 \\
\hline THC mg/l & $0.01-0.02$ & 0.1 & 0.3 \\
\hline Total Hardness mg/l & $10.0-12.0$ & 100 & 500 \\
\hline Chloride mg/l & $10.6-16.4$ & 200 & 600 \\
\hline Sulphates mg/l & $2.8-3.6$ & 200 & 400 \\
\hline Copper mg/l & $0.01-0.03$ & 0.05 & 1.5 \\
\hline Iron mg/l & $0.49-0.64$ & 1.1 & 1.0 \\
\hline Manganese mg/l & $0.01-0.03$ & 0.05 & 0.50 \\
\hline Zinc mg/l & $0.07-0.2$ & 5.0 & 15.0 \\
\hline Lead mg/l & $0.01-0.02$ & 0.05 & 0.10 \\
\hline
\end{tabular}

Conclusion: The Jisike - Izombe area is underlain by the Continental Benin Formation of Oligocene Pliocene age. The micro-stratigraphic architecture around the JES field within the area comprises a loamy topsoil, a thin near surface clayey lateritic horizon which is underlain by a high hydraulic conductivity reddish brown silty sand, gravelly in places.

Below the silty sand is a coarse-medium grained whitish sand unit which constitutes the main aquifer system in the area. Flow analysis of groundwater, which was encountered at depths below 110feet, indicates a southwesterly direction with the River Niger as possible discharge zone. Apart from the topsoil and near surface clayey laterite, the vadose zone, for the most part, consists of material indicative of properties, suggesting vulnerability of the aquifer to pollution. However measured groundwater quality parameters betray no obvious pollution, a situation that is attributable to the protection provided by the near surface clayey lateritic soil and/or good waste management practice during petroleum operations nearly two decades ago.

A risk assessment based on such other factors as local topography, vis-à-vis run off and the nature of the near-surface soil suggests that the area is not a locus of groundwater pollution. The chemical quality of the groundwater in the upper aquifer system corroborates this inference. 


\section{REFERENCES}

Adetola, B.A; David (Jr), L.M.; and Salami, S.A. (1999) "Resistivity Survey as a tool in Environmental Geophysics Studies: A Case Study" NAPE Bulletin Vol 14, No 2, pp 209 216.

Avbovbo, A.A. (1978) "Tertiary Lithostratigraphy of Niger Delta". AAPG Bulletin Vol. 62, pp $295-360$.

B.S. 1377 (1990). Methods of Testing Soils for Civil Engineering Purposes

Craig R.F. (1994). Soil Mechanics, Fifth Ed. Capman \& Hall (Pub)

Hospers, J. (1971) "The Geology of the Niger Delta area". In the Geology of the East Atlantic Continental Margin. Great Britain Institute of Geological Science Report 70, pp. 121-142.

Khalid, R.A; Gambrell, R.P.; Verloo, M.G; and Patrick, W.H. (1977). "Transformations of Heavy Metals and Plant Nutrients in Dredged Sediments as affected by Oxidation Reduction Potential and $\mathrm{pH}$ '. Vol. 1: Literature Review. Contract Report D - 77 - 4, U.S Army Engineer Water works, Experiment Station, Vicksburg, Mississippi, 221pp.

Mercer J.W. and Spalding C.P. (1991). Methods for Subsurface Characterization: Site Characterization for Subsurface Remediation: EPA/625/4-91/026 pp 13-21.
Moore, T.K. and Newbry, B.W. (1976). "Treatability of Dredged Material (Laboratory Study" Technical Report D - 76 - 2, U.S. Army Engineer Waterways Experiment Station, Vicksburg, Mississippi, 102pp.

Palmer, C.D. and Johnson, R.L. (1989). Physical Processes Controlling the Transport of NonAqueous Phase Liquids in the Subsurface. In: Transport and Fate of Contaminants in the Subsurface, EPA/625/4-89/019, pp 29 - 40.

Petts, J. and Eduljee, G. (1994). Environmental Impact Assessment for Waste Treatment and Disposal Facilities. John Wiley and Sons Ltd Chichester England (Pub).

Seelheim (1880). Zeitschrift fur Analitische Chemie (in German) Wien.

Smith G.N. (1978). Elements of Soil Mechanics for Civil and Mining Engineers. Fourth Edition, Crosby Lockwood Staples, G.B.

Short, K.C. and Stauble, A.J. (1967) "Outline of Geology of Niger Delta" AAPG Bulletin Vol. 51, pp 761-779.

Wheatcraft, S.W. (1989). An Alternate View of Contaminant Dispersion. Groundwater Monitory Review 9(3): 11-12. 